\title{
Drumlins-Trends and \\ Perspectives
}

\section{by John Menzies and James Rose}

Drumlins, those ovoid streamlined hills so common in glaciated landscapes, still remain imperfectly understood. However, recent advances have come from morphometric analysis, theoretical studies, and especially from sedimentology and soil engineering. Drumlins may be but an intermediate stage in a spectrum of subglacial forms from fluted to Rogen moraines, but whatever their precise origin they are important to society in several ways. (Ed.)

\section{The Drumlin Enigma}

The "classical" drumlin with its ovoid, streamlined shape, its occurrence en echelon in vast fields commonly of tens of thousands, and its enigmatic origin remains a puzzle to the glacial geologist (Fig. 1). The "drumlin problen" is a measure of our meagre understanding of the subglacial environment and the sedimentological and glaciological conditions that produce drumlins and other subglacial bedforms. Research on drumlins is thus central to a better understanding of processes and conditions beneath glaciers.

Research into drumlins, their morphology, sedimentology and formative processes has witnessed an enormous upsurgence of interest in the past decade. The direction of drumlin research has changed considerably since a glacial origin was first proposed in the mid-19th century. Until the mid-1970s, drumlins continued to be regarded as rather uninue glacial features that required an equally unique explanation for their origin. This approach led to much extraneous data accumulation, repetitive research and proliferation of hypotheses of origin.

Considering the expenditure of time and effort in studying drumlins, apart from Slater's classic work in New York State (1929) and a few others, virtually nothing was known of the internal sedimentology until the last ten years or so (e.g. Aario et al., 1974; Whittecar and ivickelson, 1979; Menzies, 1981; Dardis and NeCabe, 1983; Shaw and Kvill, 1984). Research up to this time followed disparate paths confined, for example, to morphological analyses, spatial statisties and landform assemblage relationships. Hypotheses of drumlin formation for particular locations, situations or sediment types then, as now, appeared at an almost geometric rate with little or no attempt made to develop general models of formation (Menzies, 1979, 1984). Yet in terms of original observations and data collection, the contributions of workers such as Upham in the Boston area, Fairchild in western New York State, or Ebers in Germany form a sound basis for much of the newer research (see Menzies, 1984).

Figure 1: A "fence" diagram illustrating the complexity of internal sediments found within arumlins.

\section{The Geotechnical Approach}

Unlike most scientific research where changes or new perspectives slowly evolved over a period of time, research in drumlins took a dramatic turn with the papers by Sinallev (1966) and Smalley and Unwin (1968). Their work heralded it new direction in drumlin research, one which is still filtering through today. The methodology of these workers, which has been termed a "geotechnical" approach, regarded druinlins from the quantitative viewpoint of soil engineering, where basal ice stresses, sediment shear strengths and the general rheology of the drumlin-forming sediment were considered. This new tack encouraged workers such ais Crozier (1975), Nenzies (1979), Whittecar and Vickelson (1979), and Zakrzewska-Borowiecki and Erickson (1985) to follow and develop this theme. However, it soon becanie apparent that more had to be known of the internal sedimentology of drumlins if an understanding of the subglacial stress "environment" was to be obtained.

At approximately the same time as the geotechnical approach developed, a sounder theoretical basis for conditions of drumlin formation began to be established. Work by Lundqvist (1970), Aario (1977), Rose and Letzer (1977), Baranowski, (1979), Boulton (1979), Shaw (1980), Menzies (1981) and several others pursued a more theoretical approach complimenting and expanding much of the research at that time.

Sedimentological, Morphometric and Theoretical Aspects

Today, three kinds of study have become established: morphometric, theoretical and sedimentological. Work by Baranowski (1977), Gluckert (1973), Jauhiainen (1975) and Mills (1980), for example, has considered, from the perspective of spatial morphometric analysis linked to known dynamic conditions of ice masses, the potential relationships that exist among drumins basal, topography, bulk sediment type, and known geochronological events.
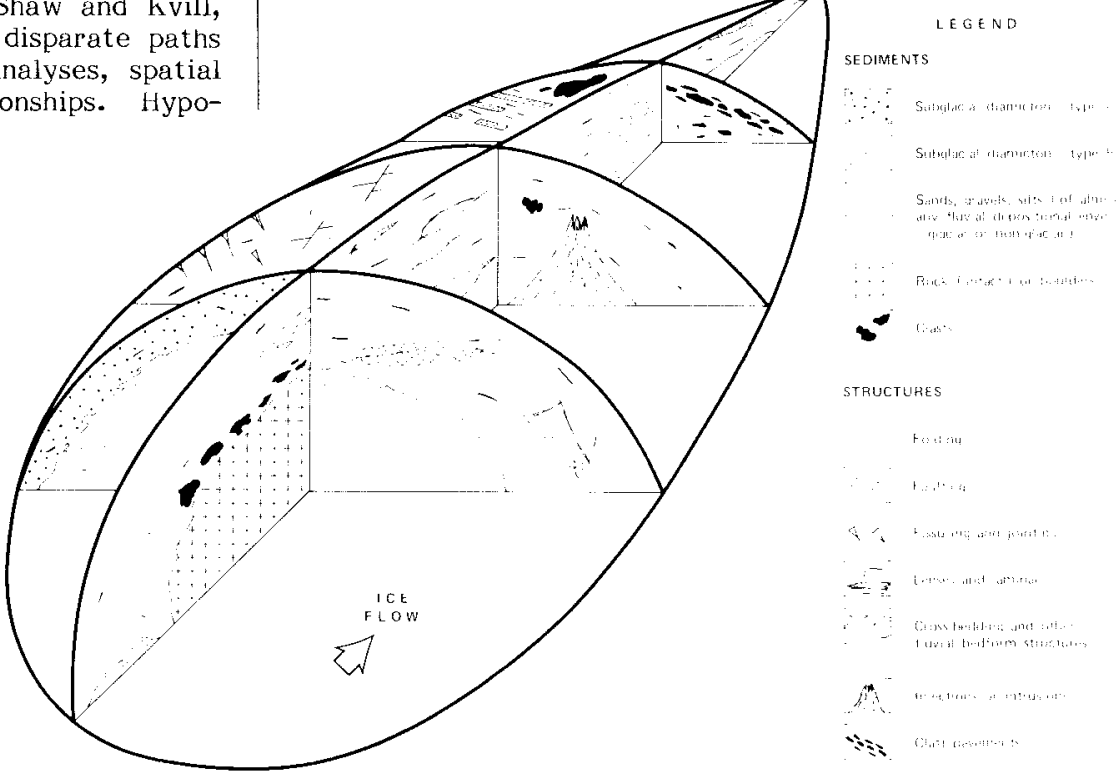
Despite the considerable amount of work on drumlins, there has been until recently a dearth of research dealing with the theoretical (glaciological and sedimentological) basis for drumlin formation. As this aspect of research develops it should provide a structure within which new ideas on drumlins can be examined. Several papers in press attempt to remedy this deficiency (see Menzies and Rose, in press). A common theme of much of this work is the view that drumlins are part of a continuum or spectrum of subglacial bedforms in the manner that these bedform associations exist in fluvial and aeolian environments (Fig. 2).

This theme is a radical departure from the "unique" approach and has broad implications for subglacial processes, lithofacies associations and related glaciodynamies. Sedimentological and bedform initiation and evolution relationships should exist (e.g. Fig. 2) between drumlins, Rogen moraines (transverse to ice flow) and some forms of fluted moraines (parallel to ice flow). Theoretical models are clearly needed to account for drumlin formation under diverse conditions at varying subglacial interfaces and of differing lithofacies.

\section{$\longrightarrow$ Ice Flow Direction}

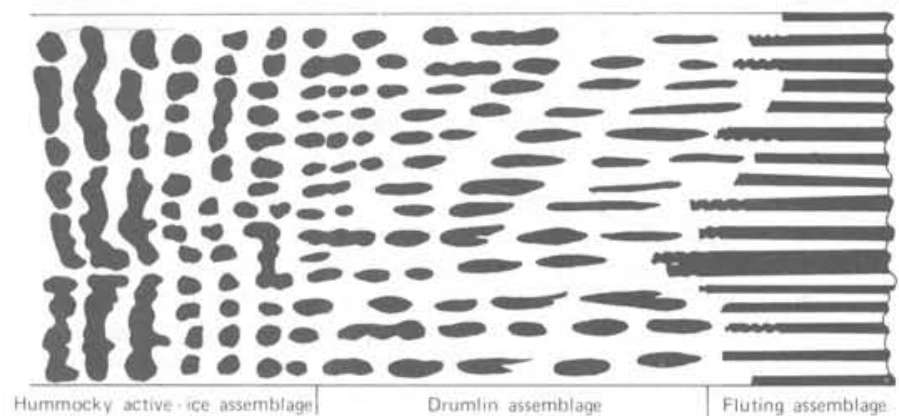

Figure 2: A plan view of the hypothetical continuum of subglacial bedforms. After Aario, 1977.

Detailed sedimentological studies of drumlin materials are also increasing. This theme is exemplified in the work of Shaw, Sharpe, Dardis, Kruger and others (see Menzies, 1984). In particular, the common presence in drumlins of sediment types from varying lithofacies environments (Fig. 3) demands a general hypothesis of drumlin formation that allows incorporation of diverse sediments in wideranging subglacial environments within markedly differing thermal and stress/strain conditions. One implication of this diversity may be that no one model will suffice, but rather that several hypotheses of distinctly different processes or groupings of processes may result in a bedform or suite of bedforms that are remarkably similar. In any case sedimentological research on drumlins is fast becoming the factual basis for all other research on these landforms; it is clearly fundamental to future developments on the drumlin "problem."

\section{Drumlins and Society}

In terms of the relationship between drumlin research and societal needs four areas stand out. First, examination of any glacial landforms is of immense value to engineers, especially when the diversity of form and sediment content is as great as in drumlins (MeGowan et al., 1974). Second, the use of drumlin sediments as part of tracer programs in geochemical exploration for gold, uranium and other minerals is reaching a level of sophistication hitherto ignored (Aario et al., 1985, and DiLabio and Coker, this issue). Third, in some countries, such as Finland, drumlins are being mapped for their potential as aggregate sources to provide for future needs of road building and formation construction projects (Haavisto-Hyvarinen, in Menzies and

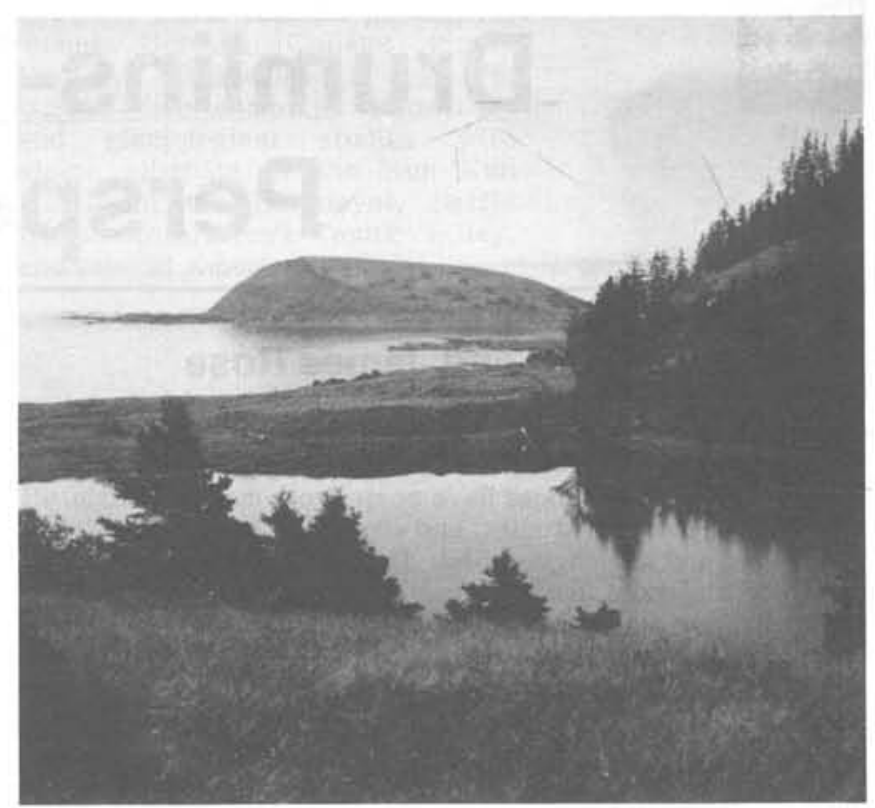

Figure 3: A drumlin on the coast of Chedabucto Bay, Nova Scotia. Photo by D.R. Grant.

Rose, in press). Finally, in the United States, the impact of drumlins in terms of planning for agriculture and soil land use within rural areas is being recognized and given greater consideration with regard to drumlin origin and sediment type (Whittecar, 1983).

INQUA '87. Special Session 15: Subglacial Bedforms Drumlins, Fluted Moraines and Ribbed Moraines. organizers: J. Menzies (Canada) and J. Rose (U.K.).

Dr. J. Menzies is Associate Professor of Geography and Geological Sciences at Brock University (St. Catharines, Ontario, Canada L2S 3Al). His research interests lie in the fields of subglacial sedimentology, glacial processes and the geotechnical aspects of glacial sediments. He has worked in Canada, Britain, Norway and the United States.

Dr. J. Rose is Reader in Geography at Birkbeck College, University of London (London, W1P 1PA, England). He works on isostatic shorelines, till petrography and sedimentation, glacier bedforms, paleosols, river sediments and landforms, and Pleistocene stratigraphy, using examples from the U.K., Scandinavia, Spain, Poland and Borneo.
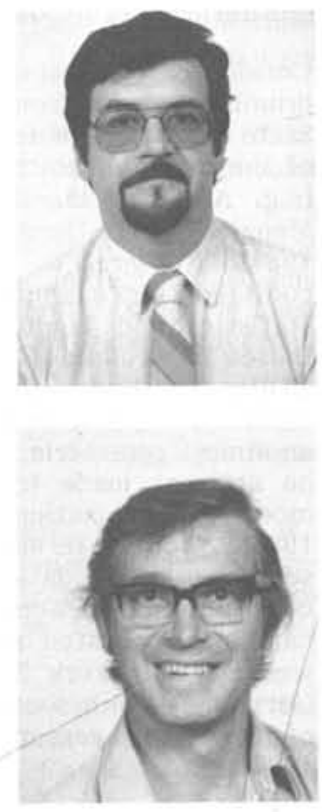
References

Aario, R., 1977. Classification and terminology of moranic landforms in Finland, Boreas, v. 6, no. 2, p. 87-100.

Aario, K., Paakkonen, K. and Saarenketo, T., 1985. Glaciodynamic dispersion of uraniunı in a Rogen enviromment, Finland. In: Abstracts of 11 th International Geochemical Exploration Symposium, Toronto, p. 37.

Aario, R., Forsstrom, L. and Lahermo, P., 1974. Glacial landforms with special reference to drumlins and fluting in isoillsmaa, Finland. Bulletin Geological Survey of Finiand, 273.

Baranowski, s., 1977. Regularity of drumlin distribution and the origin of their formation. Studia Geologica Polonica, v. 52, p. 53-68.

Baranowski, s., 1979. The origin of drumlins as an ice-rock interface problem. Journal of Glaciology, v. 23 , no. 89, p. 435-436.

Boulton, G.S., 1979. Processes of glacier erosion on different substrata. Journal of Glaciology, v. 23, no. 89, p. 15-38.

Crozier, M.J., 1975. On the origin of the Peterborough drumlin field: testing the dilatancy theory. Canadian Geographer, v. 19, no. 3, p. 181195.

Dardis, G.F. and Nccabe, A.M., 1983. Facies of subglacial channel sedimentation in Late-Pleistocene drumlins, Northern Ireland. Boreas, v. 12, no. 4 , p. $263-278$.

Gluckert, G., 1973. Two large drumlin fields in central Finland. Fennia, v. $120,37 \mathrm{p}$.

Jauhiainen, E., 1975. Norphometric analysis of drumlin fields in northern central Europe. Boreas, v. 4, p. 219-230.

Lundqvist, J., 1970. Studies of drumlin tracts in central sweden. Acta Geographica Lodziensia, v. 24, p. 317-326.

MeGown, A., salvidar-Sali, A. and Radwan, A.h., 1974. Fissure patterns and slope failures in the till at Hurlford, Ayrshire. Quarternary Journal of Engineering Geology, v. 7, no. 1, p. 1-26.

Menzies, J., 1979. A review of the literature on the formation and location of drumlins, larth Science keviews, v. 14, no. 4, p. 315-359.
Menzies, J., 1981. Investigations into the Quaternary deposits and bedroth topography of central Glasgow. Scottish Journal of Geology, v. 17, no. 3, p. $155-168$.

Menzies, J., 1984. Lrumlins: A Bibliography. Geo Books, U.K., $117 \mathrm{p}$

Menzies, J. and Rose, J. (eas.), in press. Lrumlins - 1985, Proceedings it lst Drumlin Symposium, 1985, Manchester, L.K., Balkena.

Mills, H.il,, 1980. An analysis of drumlin torm in the northeastern anti north-central United States. Cieological Society of American Bulletin, v. 91 , no. 2, p. 1637-1639, I12214-2289.

Rose, J. and Letzer, J.V., 1977. Superimposed drumlins. Journal of Glac.ology, v. 18, no. 80, p. 471-480.

Shaw, J., 1980. urumlins and large-scale flutings related to glacier folcs. Aretic and Alpine Research, v. 12, no. 3, p. 287-298.

Shaw, J., and kvill, U., 1984. A glaciofluvial origin for drumlins of the Livingstone Lake area Saskatchewan. Canadian Journal of Earth Sciences, v. 21 , no. 12 , p. $1442-1459$.

Slater, G., 1929. The structure of the drumlins exposed on the south short of Lake Ontario. New York State Nuseum Bulletin, v. 28, p. 3-19.

Smalley, I.J., 1966. Drumlin formation; a rheological model. Science, v. 151 , no. 3716 , p. $1379-1380$.

Smalley, I.J. and Unwin, L.J., 1968. The forilation and shape of drumlins and their distribution and orientation in the drumlin fields. Journal of Glaciology, v. 7 , no. 51 , p. 377-390.

Whittecar, G.R., 1983. Planning the use of soils on drumlins. Journal of Soil and water Conservation, v, 38, no. 5, p. 396-400.

Whittecar, G.K. and Hickelson, D.N., 1979. Composition, internal structures, and an hypothesis of formation for drumlins, Waukesha County, Wisconsin, U.S.A., Journal of Giaciology, v. 22, no. 87, p. 357-370.

Zakrzewska-Borowiecki, B. and Erickson, K.H., 1985. Wisconsin drumin field and its origin. Zeitschrift für Geomorphologie, v. 29, p. 417-438.
A.A.Balkema publishers of the INQUA Commission on Genesis and Lithology of Quaternary Deposits titles:

Schlüchter, Ch.

Moraines and varves: Origin, genesis, classification $1979,25 \mathrm{~cm}, 455 \mathrm{pp}$., US\$65.00

9061910390

Evenson, E.B., Ch.Schlüchter \& J.Rabassa

Tills and related deposits: Genesis, petrology, application, stratigraphy

1983, 25 cm, 464 pp., US\$65.00

9061915112

Goldthwait, R.P. \& Ch.Matsch

Genetic classifications of glacigenic deposits and their landforms

1987, 25 cm, c.350 pp., US\$55.00

9061916941

\section{FROM THE SAME PUBLISHER:}

Palaeoecology of Africa - and the surrounding islands $1966-, 22 \mathrm{~cm}, \mathrm{c} .250 \mathrm{pp}$., US\$40.00 per volume Volume 18, (June 1987) special issue dedicated to the former Editor-in-Chief, E.M.van Zinderen-Bakker.

Modern Quaternary research in southeast Asia $1975-, 23 \mathrm{~cm}$, c. 120 pp., US\$23.00 per volume Volume 10, (April 1987) The Kettledrums of southeast Asia: A Bronze Age world and its aftermath, by

A.J.Bernet Kempers (This vol. 608 pp., US\$49.50)

Quaternary of South America and Antarctic Peninsula

$1983-, 23 \mathrm{~cm}, \mathrm{c.} 160 \mathrm{pp}$., US\$28.50 per volume

Volume 4, (September 1987)

Write for full details on above titles and other publications in the field of Quaternary Research to:

A.A.BALKEMA PUBLISHERS

P.O.Box 1675, Rotterdam, Netherlands

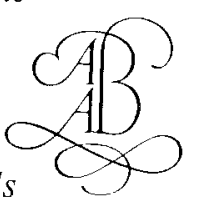

Automated Thin Section Polishing Systems

\section{In a tradition of excellence, the Logitech WG2 thin section polishing system.}

The features of the WG2 system include:

* Complete versatility

* Automatic operation

* Rugged construction

* Low operating costs

* Accepts the full range of Logitech lapping and polishing accessories.

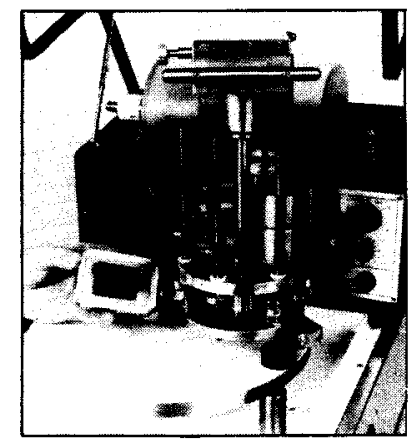

Designed for the professional laboratory which requires: The best quality surfaces

The fastest possible production rates

The most economical operation

For further details please contact:

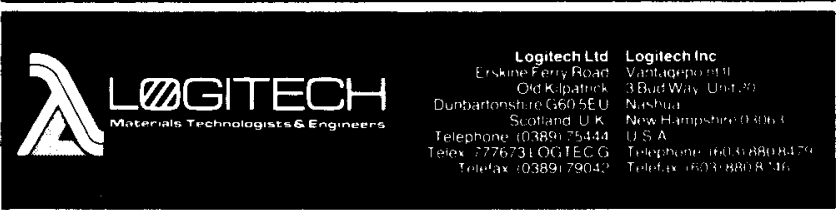

